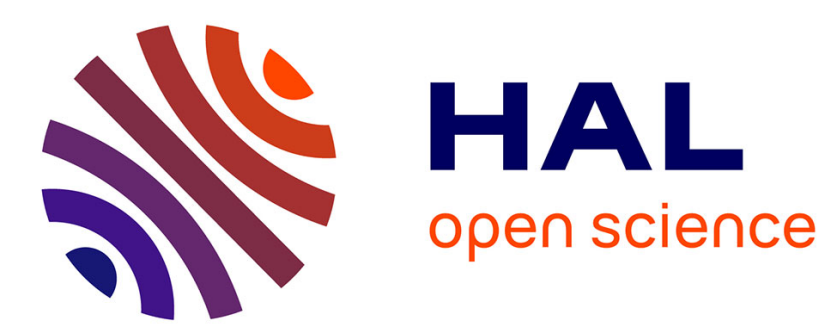

\title{
Effect of Different Nitrogen Fertilizers with Reclaimed Water Irrigation on Soil Greenhouse Gas Emissions
}

\author{
Ning Ma, Shumei Ren, Peiling Yang, Yanbing Chi, Dawei Gao
}

\section{To cite this version:}

Ning Ma, Shumei Ren, Peiling Yang, Yanbing Chi, Dawei Gao. Effect of Different Nitrogen Fertilizers with Reclaimed Water Irrigation on Soil Greenhouse Gas Emissions. 8th International Conference on Computer and Computing Technologies in Agriculture (CCTA), Sep 2014, Beijing, China. pp.185-192, 10.1007/978-3-319-19620-6_23. hal-01420231

\section{HAL Id: hal-01420231 \\ https://hal.inria.fr/hal-01420231}

Submitted on 20 Dec 2016

HAL is a multi-disciplinary open access archive for the deposit and dissemination of scientific research documents, whether they are published or not. The documents may come from teaching and research institutions in France or abroad, or from public or private research centers.
L'archive ouverte pluridisciplinaire HAL, est destinée au dépôt et à la diffusion de documents scientifiques de niveau recherche, publiés ou non, émanant des établissements d'enseignement et de recherche français ou étrangers, des laboratoires publics ou privés. 


\title{
Effect of Different Nitrogen Fertilizers with Reclaimed Water Irrigation on Soil Greenhouse Gas Emissions
}

\author{
Ning $\mathrm{Ma}^{\mathrm{a}}$, Shumei Ren ${ }^{\mathrm{b}}$, Peiling $\mathrm{Yang}^{\mathrm{c}}$, Yanbing $\mathrm{Chi}^{\mathrm{d}}$, Dawei Gao ${ }^{\mathrm{e}}$ \\ College of Water Resources and Civil Engineering, China Agricultural University, Beijing \\ 100083 \\ aningma90@163.com, ${ }^{b}$ renshumei@126.com, ${ }^{c}$ yangpeiling@126.com, ${ }^{d}$ chiice@163.com, \\ '18810395806@163.com
}

\begin{abstract}
In order to investigate the effect of using different nitrogen fertilizer with reclaimed water irrigation on the emissions of soil greenhouse gases $\left(\mathrm{CO}_{2}\right.$ and $\left.\mathrm{N}_{2} \mathrm{O}\right)$, plot experiments were conducted using clean water and reclaimed water combined with different nitrogen fertilizer (urea, ammonium sulfate, slow release fertilizer) for irrigation. No significant differences in $\mathrm{CO}_{2}$ and $\mathrm{N}_{2} \mathrm{O}$ emission flux was observed between the treatments irrigated with clean water and ones with reclaimed water. The soil $\mathrm{CO}_{2}$ emission flux had no significant relationship with the application of nitrogen fertilizer, whereas the soil emission flux increased significantly as applied with nitrogen fertilizer. The $\mathrm{N}_{2} \mathrm{O}$ emission flux reached its maximum in 2-5 days after irrigation.
\end{abstract}

Keywords: Reclaimed water, Nitrogen fertilizer, $\mathrm{CO}_{2}, \mathrm{~N}_{2} \mathrm{O}$, Emission flux

\section{Introduction}

Global warming is a critical issue challenging the security of the whole human society today. The main trigger of global warming is the excessive emission of greenhouse gas (i.e. $\mathrm{CO}_{2}, \mathrm{CH}_{4}$ and $\mathrm{N}_{2} \mathrm{O}$ ) and the contribution of these three to the greenhouse effect rate are up to $80 \%{ }^{[1]} . \mathrm{CO}_{2}$ makes the greatest contribution to adding greenhouse effect, accounting for about $60 \%$, which is the most important greenhouse gas ${ }^{[2]}$. $\mathrm{N}_{2} \mathrm{O}$ is long-lasting greenhouse gas and not only it has a warming effect, but also can damage the ozone layer. The $\mathrm{N}_{2} \mathrm{O}$ warming effect is 296 310 times of $\mathrm{CO}_{2}{ }^{[3]}$. In the process of agricultural production, agricultural greenhouse gas emissions is one of the important causes for global warming, about $5 \%-20 \% \mathrm{CO}_{2}, 15 \%-30 \% \mathrm{CH}_{4}$ and $80 \%-90 \% \mathrm{~N}_{2} \mathrm{O}$ derives from soil every year, so agricultural emission reductions allows of no delay ${ }^{[4]}$.

China is one of the 13 countries under acute water shortage and per capita water resource is only about $1 / 3$ of the world average level. In China, especially in the northern water shortage area, the use of reclaimed water has become an inevitable trend. The reclaimed water refers to the industrial wastewater or domestic sewage treated to non-potable water, which achieves a certain quality standard and can be repeatedly used in a certain extent. It is not affected by climate, convenient to use, stable, reliable and high guaranteed. It can not only reduce the discharge of sewage, 
but also reduce demand on freshwater resources. The reclaimed water has become an important supplemental source of water for agricultural irrigation production ${ }^{[5]}$. Reclaimed water as a kind of irrigation water can increase soil fertility in some degree, and the application of reclaimed water irrigation has a certain degree of security in heavy metal ${ }^{[6]}$. Water shortage will be expected to reach $1.3 \times 1010 \mathrm{~m}^{3}$ and the available quantity of reclaimed water will reach $7.67 \times 10^{10} \mathrm{~m}^{3}$ by the year $2030^{[7]}$. However, because the reclaimed water contains high concentration of nutrient, salinity, bacteria, organic matter and suspended solid particles, using reclaimed water will change soil micro environment and it may cause environmental problems including soil salinization, decreasing soil fertility and increasing agricultural greenhouse gas emission if used inappropriately ${ }^{[8]}$. In this case, the objective of this study is to investigate the effect of different nitrogen fertilizer with reclaimed water irrigation on soil greenhouse gas emissions, which may be used as a guideline for greenhouse gas emissions control in long-term sustainable use of reclaimed water.

\section{Materials and Methods}

\subsection{Experimental Material}

The experimental soil was vadose zone soil collected from the southeast suburb of Beijing irrigation area where the soil was loam at the upper $80 \mathrm{~cm}$ depth and sandy at the lower $40 \mathrm{~cm}$. Basic physical characteristics of soil are shown in Table 1.

Table 1. The basic physical parameters of experimental soils

\begin{tabular}{|c|c|c|c|c|c|c|c|}
\hline \multirow{2}{*}{$\begin{array}{l}\text { Soil } \\
\text { depth }\end{array}$} & \multicolumn{3}{|c|}{ Particle size composition（\%) } & \multirow{3}{*}{$\begin{array}{l}\text { Soil } \\
\text { texture }\end{array}$} & \multirow{2}{*}{$\begin{array}{l}\text { Bulk } \\
\text { density }\end{array}$} & \multirow{2}{*}{$\begin{array}{l}\text { Field } \\
\text { capacity }\end{array}$} & \multirow{2}{*}{$\begin{array}{l}\text { Initial } \\
\text { water } \\
\text { content }\end{array}$} \\
\hline & Clay & Silty sand & Sand & & & & \\
\hline $\mathrm{cm}$ & $<0.002 \mathrm{~mm}$ & $0.02 \sim 0.002 \mathrm{~mm}$ & $2 \sim 0.02 \mathrm{~mm}$ & & $\mathrm{~g} \cdot \mathrm{cm}^{-3}$ & $\mathrm{~cm}^{3} \cdot \mathrm{cm}^{-3}$ & $\%$ \\
\hline $0 \sim 80$ & 9.11 & 37.85 & 54.04 & Loam & 1.40 & 0.36 & 16.1 \\
\hline $80 \sim 120$ & 3.39 & 8.13 & 88.49 & Sand & 1.40 & 0.33 & 11.2 \\
\hline
\end{tabular}

The reclaimed water was secondary stage sedimentation effluent from the Qinghe sewage treatment plant. The basic parameters of irrigation water are shown in table 2 .

Table 2. Irrigation water quality parameters

\begin{tabular}{lccc}
\hline Water quality & & Clean water & Reclaimed water \\
\hline $\mathrm{pH}$ & $\mu \mathrm{S} \cdot \mathrm{cm}^{-1}$ & 7.56 & 7.97 \\
$\mathrm{EC}$ & $\mathrm{mg} \cdot \mathrm{L}^{-1}$ & $<04$ & 1010 \\
$\mathrm{BOD}_{5}$ & $\mathrm{mg} \cdot \mathrm{L}^{-1}$ & $<5$ & 3.8 \\
$\mathrm{COD}_{\mathrm{Cr}}$ & & 16.5 \\
\hline
\end{tabular}




\begin{tabular}{lccc}
\hline Organic nitrogen & $\mathrm{mg} \cdot \mathrm{L}^{-1}$ & 0.710 & 1.02 \\
Total organic carbon & $\mathrm{mg} \cdot \mathrm{L}^{-1}$ & 1.4 & 5.6 \\
Total nitrogen & $\mathrm{mg} \cdot \mathrm{L}^{-1}$ & 1.00 & 5.18 \\
\hline
\end{tabular}

\subsection{Experimental Design}

The experiment started in the water conservancy test hall in College of Water Resources and Civil Engineering, China Agricultural University from July 29, 2013. The soil tank area was $1.2 \mathrm{~m} \times 1.2 \mathrm{~m}, 1.5 \mathrm{~m}$ high. The irrigation method was surface flood irrigation. There were six treatments which were: CK, CK-APSU, RWAPSU, RW-U, RW-APS, RW-SPC (Table 3).

According to efficient water-saving irrigation system of Beijing Plain area for summer maize flat water years, the irrigation quota was $600 \mathrm{~m}^{3} / \mathrm{hm}^{2}$, simulating summer maize irrigation. Irrigation was conducted three times in the experiment. The first irrigation amount was $40 \mathrm{~L}$, the second and the third irrigation amount was $20 \mathrm{~L}$ for each treatment. Nitrogen fertilizer $\left(300 \mathrm{~kg} / \mathrm{hm}^{2}\right)$ was applied with water at the first irrigation. Test used urea with $46 \%$ nitrogen content, ammonium sulfate nitrogen content of $21 \%$ and slow-release fertilizer nitrogen content of $46 \%$.

Table 3. Fertilization treatments

\begin{tabular}{|c|c|c|c|}
\hline Treatments & $\begin{array}{l}\text { Urea } \\
\left(\mathrm{g} / \mathrm{m}^{2}\right)\end{array}$ & $\begin{array}{l}\text { Ammonium } \\
\text { sulfate } \\
\left(\mathrm{g} / \mathrm{m}^{2}\right)\end{array}$ & $\begin{array}{l}\text { Slow-release } \\
\text { fertilizer } \\
\left(\mathrm{g} / \mathrm{m}^{2}\right)\end{array}$ \\
\hline \multicolumn{4}{|l|}{ Clean water (CK) } \\
\hline $\begin{array}{l}\text { Clean water with ammonium } \\
\text { sulfate and urea (CK-APSU) }\end{array}$ & 32.61 & 71.43 & \\
\hline $\begin{array}{l}\text { Reclaimed water with ammonium } \\
\text { sulfate and urea (RW-APSU) }\end{array}$ & 32.61 & 71.43 & \\
\hline $\begin{array}{l}\text { Reclaimed water with urea (RW- } \\
\mathrm{U})\end{array}$ & 65.22 & & \\
\hline $\begin{array}{l}\text { Reclaimed water with ammonium } \\
\text { sulfate (RW-APS) }\end{array}$ & & 142.86 & \\
\hline $\begin{array}{l}\text { Reclaimed water with slow-release } \\
\text { fertilizer (RW-SPC) }\end{array}$ & & & 65.22 \\
\hline
\end{tabular}

\subsection{Experimental Methods}

The basic principle of sampling static chamber ${ }^{[9]}$ is to use the sealed bottomless boxes (made from a chemically stable material) to cover up the surface to be measured for a certain period of time and extract the gas inside. Determine trace gas concentration using chromatograph machine and then calculate the gas exchange rate of surface quilt-trace gases between ground and atmosphere according to the changing time rate of gas concentration.

Temperature and soil moisture are all important factors affecting trace gases. Therefore, in the determination of fluxes of greenhouse gas emissions, it is also 
necessary to measure the temperature and soil moisture in observation point. This experiment used TRIME tube which had been laid in the soil already, measuring water content in different soil depths $(0-10 \mathrm{~cm}, 10-20 \mathrm{~cm}, 20-40 \mathrm{~cm}, 60-80 \mathrm{~cm}, 80-$ $100 \mathrm{~cm}, 100-120 \mathrm{~cm})$ for each treatment. Domestic JM624 portable digital thermometer was used for measuring air temperature and soil temperature in observation points.

Gas sampling is generally collected at 9:00-11:00 am, for soil temperature during this period is closest to average daily temperature. Before covering the box, the tank was filled with $1 / 2$ water. After covering the boxes, we extracted gas in $0,10,20,30$ min with $40 \mathrm{~mL}$ polypropylene medical syringes which have three-way valve. Sample collection was tested by Chinese Academy of Agricultural Sciences Institute of Agricultural Environment and Sustainable Development Analysis Test Center and the analysis is completed within $24 \mathrm{~h}$. After the initial time and the last sample extraction were completed, the temperature value would record. After the gas samples was collected, using TRIME tube to measure water content in different soil depths $(0-10$, $10-20,20-40,60-80,80-100,100-120 \mathrm{~cm})$ of different treatments. Samples were collected before irrigation and at $1 \mathrm{~d}, 2 \mathrm{~d}, 5 \mathrm{~d}, 10 \mathrm{~d}, 18 \mathrm{~d}$ after irrigation.

\subsection{The data processing principle}

Flux refers to the amount of substance of unit area per unit time ${ }^{[10]}$.According to the calculation formula of sampling static chamber:

$$
F=\frac{M}{V_{0}} \frac{P}{P_{0}} \frac{T_{0}}{T} H \frac{d c}{d t}
$$

For the specific target compounds, the type $M$ is the molar mass, $P_{0}$ and $T_{0}$ are ideal gas pressure and temperature $(1013.25 \mathrm{hpa}$ and $273.15 \mathrm{~K})$ under standard conditions, $\mathrm{V}_{0}$ is the target compound molar volume in the standard state, i.e. $22.4 \mathrm{~L} \cdot \operatorname{mol}-1, \mathrm{H}$ is the sampling box chamber top space height, $\mathrm{P}$ and $\mathrm{T}$ is the actual sampling gas pressure and temperature, $\mathrm{dc} / \mathrm{dt}$ is regression curve slope of the time changing target gas concentration.

The parameters required in calculation are the actual height of sampling box $\mathrm{H}$, the sampling pressure $\mathrm{P}$, sampling temperature $\mathrm{T}$ in the box, and regression curve slope of the time changing target gas concentration $\mathrm{dc} / \mathrm{dt}$.

2.4.1The determination of actual height of sampling box $(\mathrm{H})$

The vertical distance from the bottom depth of the soil surface is defined from the water at the bottom of the base when measuring, then

The actual height $=$ sampling box height - bottom depth

In this experiment, the sampling box height is $50 \mathrm{~cm}$, the water depth is $-3 \mathrm{~cm}$, the actual height of sample box is $53 \mathrm{~cm}$, namely $\mathrm{H}=0.53 \mathrm{~m}$.

\subsubsection{The determination of pressure (P)}

Pressure of ideal gas under standard state is $101.3 \mathrm{kPa}$. The testing area pressure all year round maintains a stable value with small changes. Take a stable pressure value $100.5 \mathrm{kPa}$ as the pressure sampling value $\mathrm{P}_{0}$.

\subsubsection{The determination of temperature $(\mathrm{T})$}


The temperature $T_{0}$ is $273.15 \mathrm{~K}$ under standard conditions. The temperature value is the average temperature of the sampling process. Then use the formula $\mathrm{T}=\mathrm{t}+273.15$ to convert Celsius temperature into thermodynamic temperature.

2.4.4 The determination of regression curve slope of the time changing target gas concentration de/dt.

Detect the collected target gas concentrations, combine with the time recorded in the sampling process, and use excel to analyze regression curve slope of the time changing target gas concentration dc/dt. The dc/dt of $\mathrm{CO}_{2}$ and $\mathrm{N}_{2} \mathrm{O}$ can be calculated. Data were analyzed using SPSS 17.0 software.

\section{$3 \quad$ Results and Discussion}

\subsection{Effects of different nitrogen fertilizers with reclaimed water irrigation on soil $\mathrm{CO}_{2}$ emissions}

Figure 1 showed $\mathrm{CO}_{2}$ emission flux over time under the conditions of clean water irrigation, reclaimed water irrigation with urea, reclaimed water irrigation with ammonium sulfate and reclaimed water irrigation with slow release fertilizer. Irrigation and drainage was applied at August 7th, September 8th, September 27th. As shown in Figure 1, treatments of CK, RW-U, RW-APS had consistent gas emissions trend. Obtained from the test results, $\mathrm{CO}_{2}$ emissions increased gradually to peak at 2-5 days after each irrigation, but treatment of slow-release fertilizer peaked emission flux in the first tenth day after irrigation, later than the other three treatments. Thus, compared to $\mathrm{CK}$ water treatment, reclaimed water with urea, ammonium sulfate treatment and slow-release fertilizer had relatively higher total $\mathrm{CO}_{2}$ fluxes. However, $\mathrm{CO}_{2}$ flux emissions had a certain relationship with the soil moisture. Figure 2 showed $\mathrm{CO}_{2}$ emission flux changes with time after the clean water and reclaimed water irrigation with both ammonium sulfate and urea. In the two treatment conditions, the law of $\mathrm{CO}_{2}$ emissions was close, but RW-APSU $\mathrm{CO}_{2}$ emission flux was slightly higher than that of CK-APSU. Emission flux peaked on the second day after the first irrigation. $\mathrm{CO}_{2}$ emissions and soil moisture are clearly related. Emission peak occurred after irrigation and the first emission peak was higher than the second and third irrigation. 


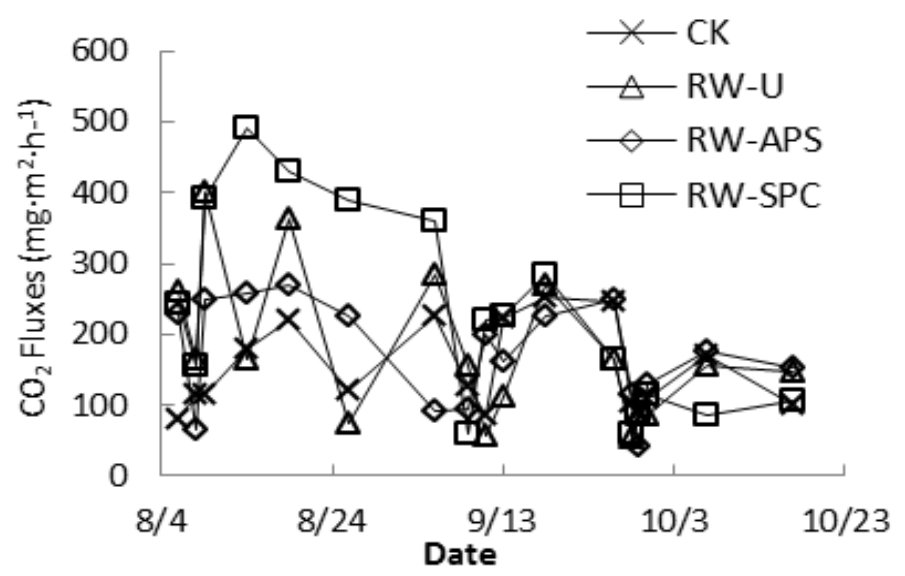

Fig. 1. Greenhouse gas emission fluxes of $\mathrm{CO}_{2}$ with the date change curve of $\mathrm{CK}, \mathrm{RW}-\mathrm{U}$, RW-APS, RW-SPC

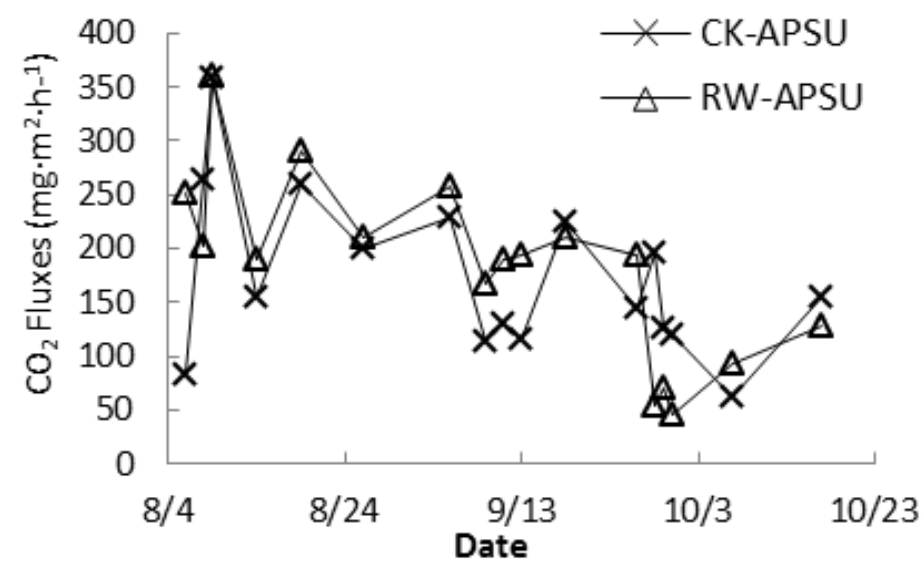

Fig. 2. Greenhouse gas emission fluxes of $\mathrm{CO}_{2}$ with the date change curve of CK-APSU, RWAPSU

\subsection{Effects of different nitrogen fertilizers with reclaimed water irrigation on soil $\mathrm{N}_{2} \mathrm{O}$ emissions}

Figure 3 was $\mathrm{N}_{2} \mathrm{O}$ emission flux over time under the conditions of clean water irrigation, reclaimed water irrigation with urea, reclaimed water irrigation with ammonium sulfate and reclaimed water irrigation with slow release fertilizer. The overall curve trend of four treatments in $\mathrm{N}_{2} \mathrm{O}$ emissions flux variation with time was consistent. August 7th, September 8th, September 27th was the three irrigating dates. As shown in fig.3, $\mathrm{N}_{2} \mathrm{O}$ emission increased gradually after irrigation. At the beginning of the experiment, the $\mathrm{N}_{2} \mathrm{O}$ had a high emission flux mainly because the 
basic fertilizer was brought into a lot of nitrogen, promoting the production of $\mathrm{N}_{2} \mathrm{O}$. As the time went, nitrogen fertilizer consumed gradually, $\mathrm{N}_{2} \mathrm{O}$ emissions had a promotion after 1 to 3 days irrigation. Along with the time advanced, because the basic fertilizer decreased and no new nitrogen added, greenhouse gas emissions flux was obviously reduced and the late emissions were near zero. Flux peak in the RW-U, RW-APS treatments appeared on the second day after first irrigation, and the peak of RW-SPC appeared on the tenth day after irrigation. There was no significant difference between $\mathrm{N}_{2} \mathrm{O}$ emission rules of urea and ammonium sulfate treatment, because urea and ammonium in the soil are decomposed into ammonium ions by promoting nitrification and denitrification. Since urea is highly volatile, it will cause some degree of volatile nitrogen loss in the fertilization process, while the hydrolysis process in the soil will cause part of the nitrogen loss, therefore, pre-emission flux of urea was high. Under different circumstances of different types of nitrogen fertilizer with water and reclaimed water, $\mathrm{N}_{2} \mathrm{O}$ emissions of reclaimed water treatment had increased to some extent, while reclaimed water contains large amounts of ammonium nitrogen, which is conductive for soil nitrification. A lot of ammonium nitrogen brought into the soil with reclaimed water irrigation would have a certain role in promoting soil $\mathrm{N}_{2} \mathrm{O}$ emissions.

Figure 4 showed $\mathrm{N}_{2} \mathrm{O}$ flux variations with time of the clean water and recycled water irrigation with ammonium sulfate and urea. Under both treatment conditions, the law of $\mathrm{N}_{2} \mathrm{O}$ emissions was nearly the same, fluxes of the reclaimed water was slightly higher than clean water, emission flux peak appeared on the second day after first irrigation. The figure showed that $\mathrm{N}_{2} \mathrm{O}$ emissions had significant relationships with nitrogen fertilizer applied. And reclaimed water had complex ingredient, it interacted with nitrogen leading to a slight increase in $\mathrm{N}_{2} \mathrm{O}$ Daily emission flux.

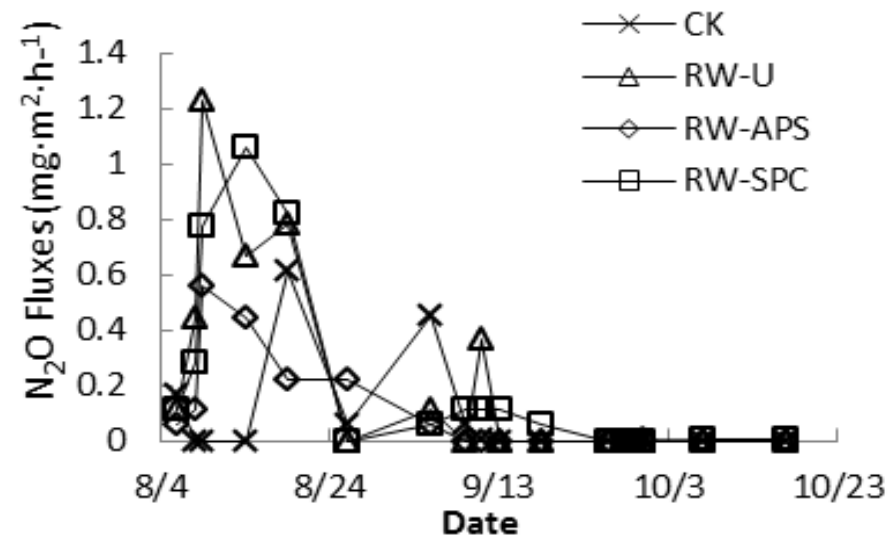

Fig. 3. Greenhouse gas emission fluxes of $\mathrm{N}_{2} \mathrm{O}$ with the date change curve of $\mathrm{CK}, \mathrm{RW}-\mathrm{U}$, RW-APS, RW-SPC 


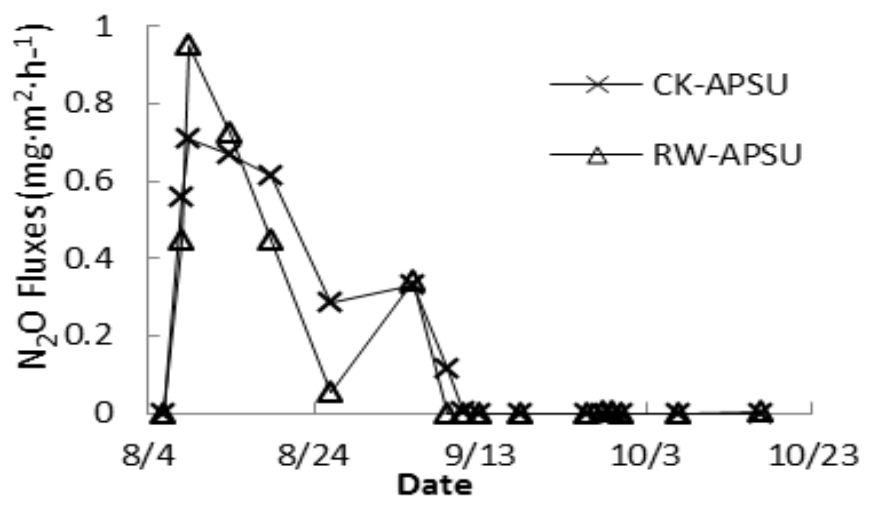

Fig. 4. Greenhouse gas emission fluxes of $\mathrm{N}_{2} \mathrm{O}$ with the date change curve of CK-APSU, RWAPSU

\section{Conclusions}

Soil greenhouse gas emissions caused by reclaimed water had a small increase compared with clean water, but the increase was not significant. Therefore the reclaimed water irrigation had no significant effect on greenhouse gas emissions.

Different nitrogen fertilizer had no significant effect on soil $\mathrm{CO}_{2}$ emissions but there was some relation with soil water content.

Soil greenhouse gases fluxes of $\mathrm{N}_{2} \mathrm{O}$ has a significant correlation with the nitrogen fertilizer applied or not, the nitrogen fertilizer application promoted soil $\mathrm{N}_{2} \mathrm{O}$ emissions. Compared with no fertilization, fertilization had significant influence on $\mathrm{N}_{2} \mathrm{O}$ emissions from agricultural soil. When using applied nitrogen fertilizer after irrigation, the soil $\mathrm{N}_{2} \mathrm{O}$ emission flux increased significantly, reaching the peak at 2-5 days after irrigation. Data were analyzed using SPSS 17.0 software, and significance level was selected at 0.05 .

The use of nitrogen fertilizer increases the $\mathrm{N}_{2} \mathrm{O}$ emissions, therefore reasonable field management measures must be taken. We can reduce the usage of nitrogen fertilizer if there is no effect on the crop yield. It will have a significant effect on reducing greenhouse gas emissions of $\mathrm{N}_{2} \mathrm{O}$ and can effectively mitigate global warming intensifies.

\section{Acknowledgment}

The experiment is a part of the project-understanding and modelling the effects of treated wastewater irrigation on Carbon and Nitrogen Circling in arable land. We greatly thank for the financial support of the National Natural Science Foundation of China (No.51279204). 


\section{References}

1. Kiehl J T, Trenberth K E. Earth's annual global mean energy budget [J]. Bulletin of the American Meteorological Society,1997, 78(2): 197-208.egf

2. IPCC. Special Report on Emissions Scenarios, Working Group III, Intergovernmental Panel on Climate Change[R].Cambridge: Cambridge University Press, 2000.

3. IPCC. Climate Change 2007: The Physical Science Basis[R].Cambridge: Cambridge University Press, 2007.

4. Zhang Yuming, Hu Chunsheng, Zhang Jiabao, et al. Research advances on source/sink intensities and greenhouse effects of $\mathrm{CO}_{2}, \mathrm{CH}_{4}$ and $\mathrm{N}_{2} \mathrm{O}$ in agricultural soils [J]. Chinese Journal of Eco-Agriculture, 2011,19 (04) :966-975.

5. Yang Linlin, Pei Ling Yang, REN Shumei, et al. Experimental Studies on Effects of Reclaimed Water Irrigation on Soil Physicochemical Properties [J]. Journal of Soil and Water Conservation, 2006,20 (2): 82 - 85.

6. Jiao Zhihua, Huang Zhanbin, Li Yong, et al. The Effect of Reclaimed Water Irrigation on Soil Performance and the Microorganism [J].Journal of Agro-Environment Science, 2010,29 (2): 319-323.

7. Liu Changming, Chen Zhikai. The analysis of Chinese water resources assessment and the tendency of supply and demand [M]. Beijing: China Water Power Press, 2001.

8. Toze S. Reuse of effluent water - benefits and risks. Agricultural Water Management, 2006,80(1-3):147-159.

9. Huang Yao. Gas exchange of carbon and nitrogen -- from the experiment to the model [M]. Beijing: China Meteorological Press, 2003:77-82.

10.Wang Yuesi, Wang Yinghong, et al. Carbon exchange of observations between Chinese terrestrial and freshwater lakes and atmosphere [M]. Beijing: Science Press, 2008. 